\title{
Synthesis and Study of the Physical and Photovoltaic Properties of Novel Heteroleptic Ruthenium(II) Complexes Ligated with Highly $\pi$-Conjugated Bipyridine Ancillary and Phenanthroline Anchoring Ligand for Dye-Sensitized Solar Cells
}

\author{
Hyejeong Lee, ${ }^{1}$ Jinhyung Seo, ${ }^{2}$ Mingyeong Jeong, ${ }^{2}$ Seo Yeong Na, Byoungchoo Park $\mathbb{D}^{3},{ }^{3}$ \\ and Byeong Hyo Kim $\mathbb{D D}^{2}$ \\ ${ }^{1}$ Department of Chemistry, Dong-A University, Busan 49315, Republic of Korea \\ ${ }^{2}$ Department of Chemistry, Kwangwoon University, Seoul 01897, Republic of Korea \\ ${ }^{3}$ Department of Electrophysics, Kwangwoon University, Seoul 01897, Republic of Korea \\ Correspondence should be addressed to Byoungchoo Park; bcpark@kw.ac.kr and Byeong Hyo Kim; bhkim@kw.ac.kr
}

Received 2 July 2021; Revised 25 October 2021; Accepted 27 October 2021; Published 22 November 2021

Academic Editor: Esteban P. Urriolabeitia

Copyright ( $) 2021$ Hyejeong Lee et al. This is an open access article distributed under the Creative Commons Attribution License, which permits unrestricted use, distribution, and reproduction in any medium, provided the original work is properly cited.

\begin{abstract}
Six new heteroleptic ruthenium(II) complexes (JM1-JM6), each bearing a highly $\pi$-conjugated bipyridine ancillary ligand (a methoxy-substituted analog $\left(\mathrm{L}_{1}\right)$ and a phenanthroline-type anchoring ligand $\left(\mathrm{L}_{2}\right)$ (dcphen or dcvphen; $\left[\mathrm{Ru}(\mathrm{L})_{2}(\mathrm{NCS})_{2}\right][\mathrm{TBA}]_{2}$; $\mathrm{L}_{1}=4,4^{\prime}$-bis $\{2$-(3,4-dimethoxyphenyl)ethenyl $\}$-2,2' -bipyridine (dmpbpy), 4,4' -bis $\{2$-(1,1' -biphenyl)-4-ylethenyl $\}$-2,2' -bipyridine (bpbpy), or 4,4'-bis $\{2$-(4'-methoxy-[1,1'-biphenyl]-4-ylethenyl $\}-2,2^{\prime}$-bipyridine (mbpbpy); $\mathrm{L}_{2}=4,7$-dicarboxy-1,10-phenanthroline (dcphen) or 4,7-bis(E-carboxyvinyl)-1,10-phenanthroline (dcvphen)) were synthesized, and their physical and photovoltaic properties were investigated. Various dye-sensitized solar cells (DSSCs) were fabricated using heteroleptic ruthenium(II) complexes. Ruthenium(II) complex JM1, ligated to dmpbpy (ancillary) and dcphen (anchoring) ligands, exhibited the maximum power conversion efficiency (PCE) value of $3.40 \%$, which was approximately $71 \%$ of the efficiency exhibited by the commercially available N719-sensitized solar cells. Ruthenium(II) complex JM5, ligated to mbpbpy (ancillary) and dcphen (anchoring) ligands, exhibited the second-best PCE value (2.52\%), and ruthenium(II) complex JM3, ligated to bpbpy (ancillary) and dcphen (anchoring) ligands, exhibited a PCE value of $1.45 \%$. It was observed that the PCE values of the DSSCs could be significantly improved by introducing the electron-donating methoxy group at proper positions of the ancillary ligands present in the heteroleptic ruthenium(II) complexes (such as JM1 and JM5).
\end{abstract}

\section{Introduction}

Dye-sensitized solar cells (DSSCs) that operate in the presence of sunlight are interesting next-generation energy devices as they are cost-effective and exhibit high-power efficiency [1]. The principles of green energy technology are followed to fabricate and operate DSSCs. DSSCs can be classified into two categories based on the types of dyes used: one is cost-effective metal-free dyes that exhibit high molar extinction coefficient and flexibility in their layout, and the other is metal-based dyes that help achieve high photovoltaic (PV) performance. Among the various metal-based systems used, systems containing ruthenium(II) complexes are studied extensively as they exhibit interesting electrochemical and photophysical properties. These properties can be attributed to the broad metal-to-ligand charge transfer (MLCT) absorption bands and suitable ground and excited state potentials [2]. The polypyridyl complexes formed with ruthenium(II) have been widely investigated as dye-sensitizers (as they are highly stable and exhibit excellent redox properties). The interest in this field grew after the publication of the results of Grätzel's pioneering research on the development of $\left[\mathrm{Ru}(\mathrm{dcbpy})_{2}(\mathrm{NCS})_{2}\right] \quad(\mathrm{N} 3), \quad\left[\mathrm{Ru}(\mathrm{dcbpy})_{2}(\mathrm{NCS})_{2}\right][\mathrm{TBA}]_{2}$ (N719) $\left(\right.$ dcbpy $=4,4^{\prime}$-dicarboxy-2,2' -bipyridine, TBA $=$ tetra 
butylammonium), and $\left[\mathrm{Ru}(\right.$ tcterpy $\left.)(\mathrm{NCS})_{3}\right][\mathrm{TBA}]_{3}$ (black dye, BD) (tcterpy $=4,4^{\prime}, 4^{\prime \prime}$-tricarboxy-2,2' $: 6^{\prime}, 2^{\prime \prime}$-terpyridine) (Figure 1(a)) [3-6].

A photosensitizer helps convert the energy of the incident sunlight (photon energy) to electrical energy. The most important component in a DSSC is the photosensitizer that helps improve the power conversion efficiency (PCE, $\eta$ ). It is important to have knowledge on molecular engineering to enhance the efficiency of the DSSCs fabricated using ruthenium(II) based dye-sensitizers. One of the strategies followed to enhance the performance includes the modification of structural features, which can potentially help in the efficient harvesting of light and achieve an improved response. Various ruthenium(II) complexes have been studied by numerous researchers, and numerous ruthenium(II) complexes have been developed using identical $\mathrm{N}, \mathrm{N}$-ligands or two different $\mathrm{N}, \mathrm{N}$-ligands (a combination of an anchoring ligand and an ancillary ligand) [7]. The primary role of the sensitizer is to convert the energy of the incident sunlight to electrical energy. In addition, the sensitizer should have the ability to get chemisorbed onto the mesoporous oxide to maximize the overall efficiency of the device. In the case of known ruthenium(II) complex sensitizers, carboxylic acid group-containing bipyridine $\mathrm{N}, \mathrm{N}$ ligand, 4,4'-dicarboxy-2,2'-bipyridine (dcbpy) was mostly used as the anchoring ligand. The discovery of BD led to studies on various terpyridine-type anchoring ligands containing ruthenium(II) for the development of complex sensitizers. Several representative examples of terpyridinetype ligands studied previously, such as $4^{\prime}$-carboxy-2, $2^{\prime}$ : $6^{\prime}, 2^{\prime \prime}$-terpyridine (cterpy, 1) [8], 4'-(4-carboxyphenyl)-2,2': $6^{\prime}, 2^{\prime \prime}$-terpyridine (cpterpy, 2) [9], $4^{\prime}$-(4-carboxyphenyleneethylene)-v-terpyridine (cpeterpy, 3) [10], 4'-(4-carboxyphenylene-ethylene-phenylene-ethylene)-v-terpyridine (cp epeterpy, 4) [10], $4^{\prime}$-thiophene-4, $4^{\prime}$-dicarboxy- $2,2^{\prime}: 6^{\prime}, 2^{\prime \prime}$ terpyridine or $4^{\prime}$-(3,4-ethylenedeoxythiophene)-4,4'-dicar boxy-2,2':6', $2^{\prime \prime}$-terpyridine (R-dcterpy, 5) [11, 12], and 2,6bis(4-carboxyquinolin-2-yl) terpyridine (cqterpy, 6) [13] are shown in Figure 1(b). The power conversion efficiencies of DSSCs fabricated using the reported systems were in the range of $2.2 \%-10 \%$. The difficulty in derivatizing the ligand limits the synthetic applications of the BD-type sensitizers. Therefore, the N3-type sensitizer bearing two different types of bipyridine ligands (ruthenium(II) complexes ligated to one dcbpy (anchoring) ligand that could be efficiently chemisorbed onto the mesoporous oxide and one ancillary ligand that bears an appropriate functionality for the conversion of the energy in incident sunlight to electrical energy) has been studied extensively to improve the performance of the solar cells $[2,14]$.

We have been trying to develop efficient photosensitizers and have primarily focused on the synthesis and application of the heteroleptic ruthenium(II) complexes as they exhibit interesting photophysical and electrochemical characteristics that can be potentially exploited to fabricate DSSC-based devices exhibiting good performances. Consequently, a series of novel heteroleptic ruthenium(II) complexes and dinuclear ruthenium(II) complexes that exhibited satisfactory PCE were synthesized. A series of compounds were synthesized by varying the ancillary and/or anchoring ligands [15-19]. During the course of our study, we realized that anchoring ligands other than the bcbpy- or terpyridinetype ligands could be used for the fabrication of efficient DSSCs.

Herein, we report the design and synthesis of new heteroleptic ruthenium(II) complex photosensitizers that are ligated to highly $\pi$-conjugated bipyridine ancillary including methoxy-substituted analog and phenanthrolinetype anchoring ligands. The systems were examined for the fabrication of DSSCs. It is important to identify appropriate ancillary and anchoring ligands for the design of a sensitizer dye that can be used for the development of DSSCs. An efficient dye must absorb light over a wide range in the electromagnetic region and exhibit a high molar extinction coefficient. Hence, bipyridine ligands containing aromatic rings in their scaffolds and bearing highly $\pi$-conjugated ethylene-phenylene and/or substituted alkoxy groups were used as the ancillary ligands. The ancillary ligands were varied to investigate the effect of $\pi$-conjugation and/or electron-donating ability of the alkoxy group (lone pair of electrons present in the system participates in conjugation) on the PCE values. The choice of the anchoring ligand is also important as efficient anchoring onto the mesoporous oxide surface can potentially improve the light-harvesting efficiency. In addition to well-known bipyridine- or terpyridine-type anchoring ligands, we attempted the less studied phenanthroline-based anchoring ligands for the fabrication of the sensitizers $[16,18]$. As it looks encouraging, we studied the 4,7-dicarboxy-1,10-phenanthroline (dcphen) ligand and its $\pi$-conjugated 4,7-bis(E-carboxyvinyl)-1,10phenanthroline (dcvphen) analog extensively in this study and determined their efficiency as anchoring ligands.

\section{Materials and Methods}

Most of the chemical reagents used in the studies were purchased from Aldrich Chemical Co. (St. Louis, MO, USA) and were used as received without further purification. All reactions were carried out under an atmosphere of dry nitrogen unless stated otherwise. The solvents were dried following the standard drying methods. 4,7-Dicarboxy-1,10phenanthroline (dcphen) and 4,7-bis(E-carboxyvinyl)-1,10phenanthroline (dcvphen) were prepared following previously reported protocols [16]. 4,4'-Bis\{2-(3,4-dimethoxyphenyl) ethenyl $\}-2,2^{\prime}$-bipyridine (dmpbpy), $4,4^{\prime}$-bis $\left\{2-\left(1,1^{\prime}\right.\right.$ biphenyl)-4-ylethenyl $\}$-2,2' -bipyridine (bpbpy), and $4,4^{\prime}$-bis $\left\{2-\left(4^{\prime}\right.\right.$-methoxy-[1,1'-biphenyl]-4-ylethenyl $\}$-2,2' -bipyridine (mbpbpy) were prepared following previously reported protocols [19].

${ }^{1} \mathrm{H}$ nuclear magnetic resonance (NMR) spectra were recorded using a $400 \mathrm{MHz}$ NMR system (Jeol, Tokyo, Japan). The chemical shifts were reported in parts per million (ppm) relative to the residual solvent peak. Tetramethylsilane (TMS) was used as an internal standard. The gas chromatography/mass spectrometry (GC/MS) technique was used to characterize the prepared organic ligands and MALDITOF mass spectrometry technique was used to characterize the heteroleptic ruthenium(II) complex photosensitizers. 
<smiles></smiles>

N3

$\left[\mathrm{Ru}(\mathrm{dcbpy})_{2}(\mathrm{NCS})_{2}\right]$

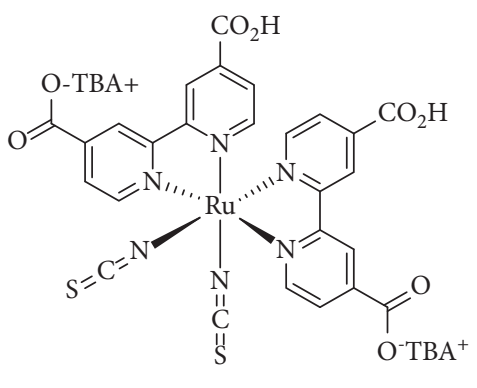

N719

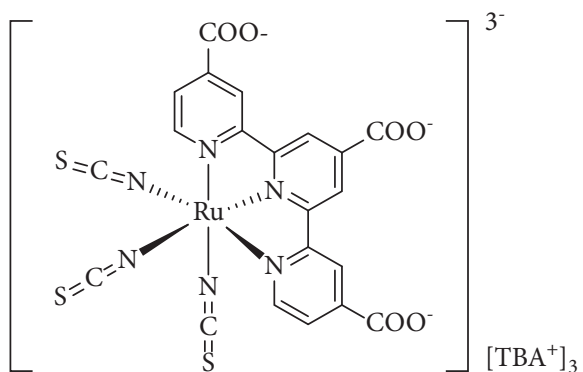

$\mathrm{BD}$

$\left[\mathrm{Ru}\left(\right.\right.$ tcterpy) $\left.(\mathrm{NCS})_{3}\right][\mathrm{TBA}]_{3}$

(a)

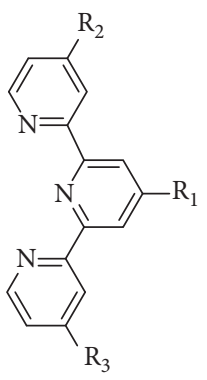

$\mathrm{R}_{1}=-\mathrm{CO}_{2} \mathrm{H}, \mathrm{R}_{2}, \mathrm{R}_{3}=\mathrm{H}: \operatorname{cterpy}(1)$

$\mathrm{R}_{1}=\leadsto \mathrm{CO}_{2} \mathrm{H}, \mathrm{R}_{2}, \mathrm{R}_{3}=\mathrm{H}: \operatorname{cpterpy}(2)$

$\mathrm{R}_{1}==\left(-\mathrm{CO}_{2} \mathrm{H}, \mathrm{R}_{2}, \mathrm{R}_{3}=\mathrm{H}, \mathrm{n}=0: \operatorname{cpeterpy}(3)\right.$ $\mathrm{n}=1: \mathrm{c}(\mathrm{pe})_{2}$ terpy $(4)$

$\mathrm{R}_{1}, \mathrm{R}_{2}=-\mathrm{CO}_{2} \mathrm{H}, \mathrm{R}_{3}=$ thiophene or EDOT $:$ R-dcterpy (5)

(b)

Figure 1: (a) Structures of N3, N719, and BD. (b) Terpyridine ligands reported previously in the literature.

The GC/MS experiments were performed using an HP 5973 mass spectrometer connected to an HP 6890 GC system (Hewlett-Packard Co., Palo Alto, California, USA). MALDITOF mass spectra were recorded on a JMS-DX303 (Jeol, Tokyo, Japan). The infrared (IR) spectra were recorded on an MB104 Fourier transform infrared (FT-IR) spectrometer (ABB Bomen Inc., Zurich, Switzerland) and the UV-vis spectra were recorded on an S-3100 spectrometer (Scinco, Seoul, Korea). The emission spectra were recorded using a luminescence spectrometer (LS 50B, excitation source: 400 nm; Perkin Elmer, Waltham, MA, USA).

2.1. General Procedure of Preparing the Monosalt Form of Ruthenium Complexes. The dimer of dichloro( $p$-cymene) ruthenium(II) (122 $\mathrm{mg}, \quad 0.20 \mathrm{mmol})$ and ligand $\mathrm{L}_{1}$ $(0.40 \mathrm{mmol})$ were dissolved in DMF $(40 \mathrm{~mL})$. The process was carried out under an atmosphere of nitrogen gas. The solution was vigorously stirred for $4 \mathrm{~h}$ in dark under nitrogen atmosphere at a temperature of $80^{\circ} \mathrm{C}$. Following this, ligand $\mathrm{L}_{2}(0.40 \mathrm{mmol})$ was added to the solution, and the solution was heated at $140^{\circ} \mathrm{C}$ for $4 \mathrm{~h}$. Subsequently, $\mathrm{NH}_{4} \mathrm{NCS}$ $(1.24 \mathrm{~g}, 16.2 \mathrm{mmol})$ was added to the reaction mixture, and the resulting mixture was heated at $140^{\circ} \mathrm{C}$ for an additional $4 \mathrm{~h}$. After the evaporation of DMF, the resulting residue was suspended in water, filtered following the process of suction filtration, and dried to obtain the acid form of the ruthenium complexes. The acid form of the ruthenium complex was dissolved in a solution of tetrabutylammonium hydroxide $(20 \mathrm{~mL} ; 10 \%)$. The solution was stirred for $30 \mathrm{~min}$ to $1 \mathrm{~h}$, following which the reaction mixture was filtered using a sintered glass funnel. The compound was purified using an LH-20 Sephadex column loaded using methanol. The adsorbed complex was eluted using methanol. The compound corresponding to the major band in the column was collected, and the $\mathrm{pH}$ of the solution was lowered to $3.8 \mathrm{using}$ an aqueous (aq.) solution of $\mathrm{HNO}_{3}(0.5 \mathrm{M})$. At this $\mathrm{pH}$, most of the complex precipitated out. The flask containing the complex was stored in a refrigerator for $12 \mathrm{~h}$. The contents of the flask were filtered using a sintered glass funnel, and the precipitate was collected. The isolated solid was washed with water $(5 \mathrm{~mL} ; \mathrm{pH}=3.8)$. The product was kept in a vacuum oven for drying.

Tetrabutylammonium $\quad\left[\right.$ cis- $4,4^{\prime}$-bis $\{2-(3,4$-dimethoxyphenyl) ethenyl $\}-2,2^{\prime}$-bipyridine-(4,7-dicarboxy-1,10-ph enanthroline)-di(thiocyanato)] ruthenium(II) (JM1, $\mathrm{C}_{62}$ $\mathrm{H}_{71} \mathrm{~N}_{7} \mathrm{RuS}_{2} \mathrm{O}_{8}$ ): yield: $48 \%$; ${ }^{1} \mathrm{H}$ NMR (400 MHz, DMSO- $d_{6}$ ): $\delta 9.66(\mathrm{~d}, 1 \mathrm{H}, J=8.0 \mathrm{~Hz}), 9.21(\mathrm{~d}, 1 \mathrm{H}, J=3.2 \mathrm{~Hz}), 9.05(\mathrm{~d}, 1 \mathrm{H}$, $J=8.0 \mathrm{~Hz}), 8.88(\mathrm{~d}, 1 \mathrm{H}, J=10.8 \mathrm{~Hz}), 8.70(\mathrm{~d}, 1 \mathrm{H}, J=11.2 \mathrm{~Hz})$, $8.45(\mathrm{~s}, 1 \mathrm{H}), 8.08(\mathrm{~d}, 1 \mathrm{H}, J=5.2 \mathrm{~Hz}), 8.00(\mathrm{~s}, 1 \mathrm{H}), 7.86(\mathrm{~d}, 1 \mathrm{H}$, $J=16.0 \mathrm{~Hz}), 7.80(\mathrm{~d}, 1 \mathrm{H}, J=5.6 \mathrm{~Hz}), 7.55(\mathrm{~d}, 1 \mathrm{H}, J=16.2 \mathrm{~Hz})$, $7.42-7.36(\mathrm{~m}, 2 \mathrm{H}), 7.33(\mathrm{~d}, 1 \mathrm{H}, J=8.0 \mathrm{~Hz}), 7.25-7.21(\mathrm{~m}$, 2H), 7.17-7.11 (m, 4H), 7.03-7.01 (m, 2H), $3.91(\mathrm{~s}, 3 \mathrm{H}), 3.86$ $(\mathrm{s}, 3 \mathrm{H}), 3.82(\mathrm{~s}, 3 \mathrm{H}), 3.80(\mathrm{~s}, 3 \mathrm{H}), 3.18-3.14(\mathrm{~m}, 8 \mathrm{H})$, $1.61-1.54(\mathrm{~m}, 8 \mathrm{H}), 1.35-1.27(\mathrm{~m}, 8 \mathrm{H}), 0.94(\mathrm{t}, 12 \mathrm{H}$, $J=7.2 \mathrm{~Hz}$ ); IR (neat): 3451, 3043, 2992, 2098, 1702, 1612, $1373 \mathrm{~cm}^{-1}$; UV/vis (DMSO) 272, 370, 449, $539 \mathrm{~nm}$; MALDITOF: $\mathrm{m} / \mathrm{z}=583.40 \quad\left((\mathrm{M}-\mathrm{dcphen}-2 \mathrm{NCS}-\mathrm{TBA}+\mathrm{H})^{+}, \quad\right.$ calc. 583.12). 
Journal of Chemistry

Tetrabutylammonium [cis-4,4'-bis $\{2-(3,4-d i m e t h o x-$ yphenyl) ethenyl\}-2,2' -bipyridine-(4,7-bis( $E$-carboxyviny 1)-1,10-phenanthroline)-di(thiocyanato)] ruthenium(II) (JM2, $\mathrm{C}_{66} \mathrm{H}_{75} \mathrm{~N}_{7} \mathrm{RuS}_{2} \mathrm{O}_{8}$ ): yield: $52 \%$; ${ }^{1} \mathrm{H}$ NMR $(400 \mathrm{MHz}$, DMSO- $\left.d_{6}\right): \delta 9.59(\mathrm{~d}, 1 \mathrm{H}, J=5.2 \mathrm{~Hz}), 9.22(\mathrm{~d}, 1 \mathrm{H}, J=6.0 \mathrm{~Hz})$, $8.91(\mathrm{~s}, 1 \mathrm{H}), 8.73(\mathrm{~s}, 1 \mathrm{H}), 8.61(\mathrm{~d}, 1 \mathrm{H}, J=9.6 \mathrm{~Hz}), 8.55(\mathrm{~d}, 1 \mathrm{H}$, $J=4.4 \mathrm{~Hz}), 8.49(\mathrm{~d}, 1 \mathrm{H}, J=9.2 \mathrm{~Hz}), 8.43(\mathrm{~d}, 1 \mathrm{H}, J=15.6 \mathrm{~Hz})$, $8.19(\mathrm{~d}, 1 \mathrm{H}, J=15.6 \mathrm{~Hz}), 8.03(\mathrm{~s}, 1 \mathrm{H}), 7.98(\mathrm{~d}, 1 \mathrm{H}, J=5.2 \mathrm{~Hz})$, $7.57(\mathrm{~d}, 1 \mathrm{H}, J=16.4 \mathrm{~Hz}), 7.40-7.32(\mathrm{~m}, 3 \mathrm{H}), 7.31(\mathrm{~d}, 1 \mathrm{H}$, $J=8.4 \mathrm{~Hz}), 7.27(\mathrm{~d}, 1 \mathrm{H}, J=5.6 \mathrm{~Hz}), 7.24(\mathrm{~s}, 1 \mathrm{H}), 7.17-7.09$ $(\mathrm{m}, 3 \mathrm{H}), 7.05-6.99(\mathrm{~m}, 4 \mathrm{H}), 6.77(\mathrm{~d}, 1 \mathrm{H}, J=15.2 \mathrm{~Hz}), 3.90(\mathrm{~s}$, $3 \mathrm{H}), 3.85(\mathrm{~s}, 3 \mathrm{H}), 3.81(\mathrm{~s}, 3 \mathrm{H}), 3.77(\mathrm{~s}, 3 \mathrm{H}), 3.19-3.14(\mathrm{~m}$, $8 \mathrm{H}), 1.62-1.54(\mathrm{~m}, 8 \mathrm{H}), 1.37-1.28(\mathrm{~m}, 8 \mathrm{H}), 0.94(\mathrm{t}, 12 \mathrm{H}$, $J=7.6 \mathrm{~Hz}$ ); IR (neat): 3411, 3063, 2962, 2098, 1697, 1612, $1373 \mathrm{~cm}^{-1}$; UV/vis (DMSO) 293, 361, $549 \mathrm{~nm}$; MALDI-TOF: $\mathrm{m} / \mathrm{z}=583.46\left((\mathrm{M}-\mathrm{dcvphen}-2 \mathrm{NCS}-\mathrm{TBA}+\mathrm{H})^{+}\right.$, calc. 583.12).

Tetrabutylammonium [cis-4,4' -bis $\left\{2-\left(1,1^{\prime}\right.\right.$-biphenyl)-4ylethenyl\}-2,2'-bipyridine-(4,7-dicarboxy-1,10-phenanthro line)-di(thiocyanato)] ruthenium(II) (JM3, $\mathrm{C}_{70} \mathrm{H}_{71} \mathrm{~N}_{7} \mathrm{RuS}_{2}$ $\left.\mathrm{O}_{4}\right)$ : yield: $79 \% ;{ }^{1} \mathrm{H}$ NMR $\left(400 \mathrm{MHz}, \mathrm{DMSO}-d_{6}\right): \delta 9.68(\mathrm{~d}$, $1 \mathrm{H}, J=5.2 \mathrm{~Hz}), 9.32(\mathrm{~d}, 1 \mathrm{H}, J=5.6 \mathrm{~Hz}), 9.07(\mathrm{~d}, 1 \mathrm{H}$, $J=8.4 \mathrm{~Hz}), 9.01(\mathrm{~s}, 1 \mathrm{H}), 8.96(\mathrm{~d}, 1 \mathrm{H}, J=9.2 \mathrm{~Hz}), 8.82(\mathrm{~s}, 1 \mathrm{H})$, $8.46(\mathrm{~d}, 1 \mathrm{H}, J=4.8 \mathrm{~Hz}), 8.06-8.02(\mathrm{~m}, 1 \mathrm{H}), 8.00(\mathrm{~d}, 1 \mathrm{H}$, $J=16.0 \mathrm{~Hz}), 7.91-7.83(\mathrm{~m}, 4 \mathrm{H}), 7.82-7.77(\mathrm{~m}, 4 \mathrm{H}), 7.73-7.69$ $(\mathrm{m}, 5 \mathrm{H}), 7.63(\mathrm{~d}, 1 \mathrm{H}, J=16.0 \mathrm{~Hz}), 7.59(\mathrm{~d}, 1 \mathrm{H}, J=16.0 \mathrm{~Hz})$, 7.54-7.45 (m, 5H). 7.43-7.37 (m, 3H), $7.32(\mathrm{~d}, 1 \mathrm{H}, J=6.0 \mathrm{~Hz})$, $7.25(\mathrm{~d}, 1 \mathrm{H}, J=16.0 \mathrm{~Hz}), 3.20-3.16(\mathrm{~m}, 8 \mathrm{H}), 1.65-1.57(\mathrm{~m}$, $8 \mathrm{H}), 1.39-1.30(\mathrm{~m}, 8 \mathrm{H}), 0.95(\mathrm{t}, 12 \mathrm{H}, J=7.6 \mathrm{~Hz})$; IR (neat): $3425,3061,2962,2098,1682,1612,1386,1028 \mathrm{~cm}^{-1}$; UV/vis (DMSO) 276, 350, 448, $550 \mathrm{~nm}$; MALDI-TOF: $\mathrm{m} / \mathrm{z}=613.28$ ((M-dcphen-2NCS-TBA-H $)^{+}$, calc. 613.12).

Tetrabutylammonium [cis-4,4'-bis $\left\{2-\left(1,1^{\prime}\right.\right.$-biphenyl)4-ylethenyl\}-2,2' -bipyridine-(4,7-bis(E-carboxyvinyl)-1, 10-phenanthroline)-di(thiocyanato)] ruthenium(II) (JM4, $\left.\mathrm{C}_{74} \mathrm{H}_{75} \mathrm{~N}_{7} \mathrm{RuS}_{2} \mathrm{O}_{4}\right)$ : yield: 71\%; ${ }^{1} \mathrm{H}$ NMR $(400 \mathrm{MHz}$, DMSO$\left.d_{6}\right): \delta 9.62(\mathrm{~d}, 1 \mathrm{H}, J=5.6 \mathrm{~Hz}), 9.28(\mathrm{~d}, 1 \mathrm{H}, J=4.8 \mathrm{~Hz}), 8.97(\mathrm{~s}$, $1 \mathrm{H}), 8.79(\mathrm{~s}, 1 \mathrm{H}), 8.60-8.54(\mathrm{~m}, 2 \mathrm{H}), 8.48-8.40(\mathrm{~m}, 2 \mathrm{H}), 8.18$ $(\mathrm{d}, 1 \mathrm{H}, J=14.4 \mathrm{~Hz}), 8.01(\mathrm{~d}, 1 \mathrm{H}, J=6.0 \mathrm{~Hz}), 7.98-7.94(\mathrm{~m}$, 2H), 7.87-7.80 (m, 5H), 7.75-7.63 (m, 10H), 7.56-7.53 (m, $2 \mathrm{H}), 7.39-7.32(\mathrm{~m}, 3 \mathrm{H}), 7.30(\mathrm{~m}, 3 \mathrm{H}), 7.23(\mathrm{~d}, 1 \mathrm{H}$, $J=16.0 \mathrm{~Hz}), \quad 7.07(\mathrm{~d}, 1 \mathrm{H}, J=14.4 \mathrm{~Hz}), 6.72(\mathrm{~d}, 1 \mathrm{H}$, $J=16.0 \mathrm{~Hz}$ ), $3.34-3.20(\mathrm{~m}, 8 \mathrm{H}), 1.61-1.53$ (m, $8 \mathrm{H}), 1.36-1.26$ (m, $8 \mathrm{H}), 0.92(\mathrm{t}, 12 \mathrm{H}, J=6.8 \mathrm{~Hz})$; IR (neat): 3441, 2962, 2098, 1697, 1612, 1311, $1018 \mathrm{~cm}^{-1}$; UV/vis (DMSO) 299, 341, 466, $555 \mathrm{~nm}$; MALDI-TOF: $\mathrm{m} / \mathrm{z}=613.26$ ((M-dcvphen-2NCSTBA-H $)^{+}$, calc. 613.12).

Tetrabutylammonium [cis-4,4'-bis $\left\{2-\left(4^{\prime}\right.\right.$-methoxy-[1, $1^{\prime}$-biphenyl]-ylethenyl\}-2,2' -bipyridine-(4,7-dicarboxy-1, 10-phenanthroline)-di(thiocyanato)] ruthenium(II) (JM5, $\left.\mathrm{C}_{72} \mathrm{H}_{75} \mathrm{~N}_{7} \mathrm{O}_{6} \mathrm{RuS}_{2}\right)$ : yield: $75 \%$; ${ }^{1} \mathrm{H}$ NMR $(400 \mathrm{MHz}$, DMSO$\left.d_{6}\right): \delta 9.69(\mathrm{~d}, 1 \mathrm{H}, J=5.0 \mathrm{~Hz}), 9.31(\mathrm{~d}, 1 \mathrm{H}, J=6.4 \mathrm{~Hz}), 9.08(\mathrm{~s}$, $1 \mathrm{H}), 8.98-8.94(\mathrm{~m}, 2 \mathrm{H}), 8.78(\mathrm{~s}, 1 \mathrm{H}), 8.45(\mathrm{~d}, 1 \mathrm{H}, J=4.6 \mathrm{~Hz})$, 8.12-8.05 (m, 2H), $7.97(\mathrm{~d}, 1 \mathrm{H}, J=16.0 \mathrm{~Hz}), 7.88-7.84(\mathrm{~m}$, $2 \mathrm{H}), 7.81-7.77(\mathrm{~m}, 3 \mathrm{H}), 7.74-7.61(\mathrm{~m}, 9 \mathrm{H}), 7.54(\mathrm{~d}, 1 \mathrm{H}$, $J=16.0 \mathrm{~Hz}), 7.30(\mathrm{~d}, 1 \mathrm{H}, J=6.4 \mathrm{~Hz}), 7.23-7.17(\mathrm{~m}, 2 \mathrm{H})$, 7.10-7.01 (m, 4H), $3.85(\mathrm{~s}, 3 \mathrm{H}), 3.82(\mathrm{~s}, 3 \mathrm{H}), 3.20-3.16(\mathrm{~m}$, $8 \mathrm{H}), 1.65-1.57(\mathrm{~m}, 8 \mathrm{H}), 1.37-1.30(\mathrm{~m}, 8 \mathrm{H}), 0.95(\mathrm{t}, 12 \mathrm{H}$, $J=7.2 \mathrm{~Hz}$ ); IR (neat): 3427, 3064, 2966, 2095, 1686, 1617, 1390, $1024 \mathrm{~cm}^{-1}$; UV/vis (DMSO) 270, 363, 439, $536 \mathrm{~nm}$;
MALDI-TOF: $\mathrm{m} / \mathrm{z}=673.23$ ((M-dcphen-2NCS-TBA-H $)^{+}$, calc. 673.14).

Tetrabutylammonium [cis-4, $\mathbf{4}^{\prime}$-Bis $\left\{2-\left(\mathbf{4}^{\prime}\right.\right.$-methoxy-[1, $1^{\prime}$-biphenyl]-ylethenyl\}-2,2' -bipyridine-(4,7-bis $(E$-carbox y-vinyl)-1,10-phenanthroline)-di(thiocyanato)] rutheniu m(II) (JM6, $\mathrm{C}_{76} \mathrm{H}_{79} \mathrm{~N}_{7} \mathrm{O}_{6} \mathrm{RuS}_{2}$ ): yield: $75 \% ;{ }^{1} \mathrm{H} \quad \mathrm{NMR}$ $\left(400 \mathrm{MHz}, \mathrm{DMSO}-d_{6}\right): \delta 9.68(\mathrm{~d}, 1 \mathrm{H}, J=5.6 \mathrm{~Hz}), 9.28(\mathrm{~d}, 1 \mathrm{H}$, $J=4.8 \mathrm{~Hz}), 8.91(\mathrm{bd} \mathrm{s}, 1 \mathrm{H}), 8.72(\mathrm{bd} \mathrm{s}, 1 \mathrm{H}), 8.62(\mathrm{~d}, 1 \mathrm{H}$, $J=4.8 \mathrm{~Hz}), 8.51(\mathrm{~s}, 1 \mathrm{H}), 8.46(\mathrm{~s}, 1 \mathrm{H}), 8.28-8.24(\mathrm{~m}, 2 \mathrm{H}), 8.07$ $(\mathrm{d}, 1 \mathrm{H}, J=5.5 \mathrm{~Hz}), 7.96(\mathrm{~s}, 1 \mathrm{H}), 7.92(\mathrm{~s}, 1 \mathrm{H}), 7.89-7.84(\mathrm{~m}$, $3 \mathrm{H}), 7.83-7.79(\mathrm{~m}, 3 \mathrm{H}), 7.75-7.63(\mathrm{~m}, 9 \mathrm{H}), 7.50(\mathrm{~d}, 1 \mathrm{H}$, $J=16.0 \mathrm{~Hz}), 7.29(\mathrm{~d}, 1 \mathrm{H}, J=4.8 \mathrm{~Hz}), 7.22-7.15(\mathrm{~m}, 2 \mathrm{H})$, 7.10-7.01 (m, 4H), $6.76(\mathrm{~d}, 1 \mathrm{H}, J=16.0 \mathrm{~Hz}), 3.84(\mathrm{~s}, 3 \mathrm{H}), 3.81$ (s, 3H), 3.21-3.17 (m, 8H), 1.65-1.58 (m, 8H), 1.40-1.31 (m, $8 \mathrm{H}), 0.96(\mathrm{t}, 12 \mathrm{H}, J=7.2 \mathrm{~Hz}$ ); IR (neat): $3450,2977,2102$, $1702,1634,1326,1056 \mathrm{~cm}^{-1}$; UV/vis (DMSO): 269, 294, 353, $551 \mathrm{~nm}$; MALDI-TOF: $\mathrm{m} / \mathrm{z}=673.23$ ((M-dcvphen-2NCSTBA-H) $)^{+}$, calc. 673.14).

2.2. Fabrication and Characterization of DSSCs. The $\mathrm{TiO}_{2}$ colloid was prepared: $\mathrm{TiO}_{2}(3.0 \mathrm{~g}$, Degussa P25) and acetylacetone $(0.27 \mathrm{~mL})$ were added to a container containing distilled water $(17 \mathrm{~mL})$. The mixture was ultrasonicated for $10 \mathrm{~min}$, following which the surfactant Triton X-100 $(0.13 \mathrm{~mL})$, polyethylene glycol $(0.75 \mathrm{~g}, \mathrm{PEG}-20000)$, and poly (ethylene oxide) ( $0.15 \mathrm{~g}$, PEO-2000000) were added to the solution. The porous $\mathrm{TiO}_{2}$-film was then deposited on a wellcleaned indium tin oxide (ITO) conducting glass following the doctor blade method. Following this, the material was sintered at $450^{\circ} \mathrm{C}$ for $30 \mathrm{~min}$. A complex dye sensitization process was conducted using JM1-JM6 by soaking the porous film for $18 \mathrm{~h}$ in isopropyl alcohol $(0.20 \mathrm{wt} . \% ; 2.0 \mathrm{mg}$ $\mathrm{H}$-series/1 $\mathrm{g}$ isopropyl alcohol). The dye N719 was used as a reference (Solaronix SA, Aubonne, Switzerland). An electrolyte (consisting of $\mathrm{I}_{2}(0.05 \mathrm{M})$, LiI $(0.50 \mathrm{M})$, and tertbutylpyridine $(0.50 \mathrm{M})$ dissolved in acetonitrile) was then spread on the sensitized semiconductor layer following the process of spin coating. Following this, the Pt counterelectrode was introduced into the system. The DSSCs were fabricated using a glass substrate/ITO/porous $\mathrm{TiO}_{2} / \mathrm{JM}$-series complex dye/electrolyte/Pt. The performances of the DSSCs were determined under an illumination intensity of $100 \mathrm{~mW} \cdot \mathrm{cm}^{-2}$ generated by an AM 1.5 light source $(96000$ Solar Simulator, Newport Corporation, Irvine, CA, USA). The active area of the DSSCs was set to $0.36 \mathrm{~cm}^{2}$. The photocurrent characteristics were measured using a source meter (2400 Keithley, Cleveland, OH, USA). A reference solar cell (BS-520, Bunkohkoiki, Tokyo, Japan) was used for calibration. The devices were characterized at room temperature under ambient conditions.

\section{Results and Discussion}

3.1. Synthesis. Two phenanthroline-based anchoring ligands functionalized with carboxylic acid groups and three highly $\pi$-conjugated and/or methoxy-incorporated conjugated bipyridine ancillary ligands were prepared for the synthesis of the new heteroleptic ruthenium(II) complex sensitizers 
for the fabrication of DSSC materials (Scheme 1). The anchoring ligands, which would enable the efficient chemisorption of the sensitizers onto the mesoporous oxide (dcphen and its $\pi$-conjugated dcvphen analog), were synthesized following reported protocols (Scheme 1(a)) $[16,18]$. Three ancillary ligands (4,4'-bis $\{2$-(3,4-dimethoxyphenyl) ethenyl $\}-2,2^{\prime}$-bipyridine (dmpbpy), 4,4'-bis $\left\{2\right.$-(1, $1^{\prime}$-biphenyl)-4-ylethenyl $\}-2,2^{\prime}$-bipyridine (bpbpy), and $4,4^{\prime}$-bis $\{2$ (4'-methoxy-[1,1'-biphenyl]-4-ylethenyl\}-2,2'-bipyridine (mbpbpy)) were synthesized over multiple steps starting from 4,4'-dimethylbipyridine following the methods reported in the literature [19]. First, 4,4'-dimethylbipyridine was converted to the phosphonate-functionalized bipyridine intermediate 4,4'-bis (diethylphosphonomethyl)-2,2' bipyridine (7). The compound could be used as a precursor of the ancillary ligands. The prepared compound was used as a substrate in the Wittig cross-coupling reaction and was reacted with the appropriate benzaldehyde derivative $(\mathbf{8}, \mathbf{9}$, or 10) to synthesize the three essential ancillary ligands needed for our studies (Scheme 1(b)).

Prepared two anchoring ligands and three ancillary ligands were used for the synthesis of six new heteroleptic ruthenium(II) complexes (Scheme 2). Ruthenium(II) complexes (11a-11f; $\left.\left[\mathrm{Ru}\left(\mathrm{L}_{1}\right)\left(\mathrm{L}_{2}\right)(\mathrm{NCS})_{2}\right]\right)$ containing carboxylic acid-functionalized anchoring and ancillary ligands were prepared following a typical one-pot procedure (Seo et al., 2019). $\left[\mathrm{RuCl}_{2}(p \text {-cymene })\right]_{2}$ was reacted with an ancillary ligand $\left(\mathrm{L}_{1}=\mathrm{dmpbpy}\right.$, bpbpy, or mbpbpy) in $N, N^{\prime}$ dimethylformamide (DMF) as the solvent under an atmosphere of nitrogen in the dark. The synthesized compound was further reacted with an anchoring ligand $(\mathrm{L}=\mathrm{dcphen}$ or $\mathrm{dcvphen}$ ), and the resulting product was treated with a large excess of ammonium thiocyanate (Scheme 2). Following this, the prepared acid form of the precipitate (11a-11f) was dissolved in a solvent system consisting of $10 \%$ tetrabutylammonium hydroxide and $\mathrm{MeOH}$. The impurities were filtered off, and the solvent was removed. The solution was purified using a Sephadex LH-20 column with methanol as the eluent. The resulting solid was treated with $\mathrm{HNO}_{3}(0.1 \mathrm{~N})$ to obtain the desired products (JM1-JM6; $\left[\mathrm{Ru}\left(\mathrm{L}_{1}\right)\left(\mathrm{L}_{2}\right)\right.$ $\left.\left.(\mathrm{NCS})_{2}\right][\mathrm{TBA}]\right)$. The products were obtained in moderate yields (48-79\%; two-step complexation reaction).

3.2. Ultraviolet-Visible (UV-Vis) Studies. The UV-vis absorption spectra recorded for JM1-JM6 (ruthenium(II) complexes) have been shown in Figure 2. The energy maxima $\left(\lambda_{\max }\right)$ and coefficients $(\varepsilon)$ are summarized in Table 1. For comparison, the UV-vis absorption spectrum of the well-known N719 has been shown in Figure 2. The data obtained by analyzing the UV-vis spectra recorded with N719 and the previously reported compound H3 (ruthenium(II) complex ligated to $4,4^{\prime}$-bis((E)-styryl)-2,2' bipyridine (bsbpy) and dcphen [18]) have also been listed in Table 1 for reference. The experiments were conducted with the compounds dissolved in DMSO (concentration: $1 \times 10^{-4} \mathrm{M}$ ). The series of six new heteroleptic $\mathrm{Ru}(\mathrm{II})$ complexes exhibited unique $\lambda_{\max }$ and $\varepsilon$ values. The recorded $\lambda_{\text {max }}$ and $\varepsilon$ values were different than the values recorded for the reference N719 and H3 dyes, which have absorption bands covering a wide spectral range (from near UV to visible range). Absorption bands shown in the high-energy region in the UV region at approximately $300 \mathrm{~nm}$ were assigned to the intraligand $\pi-\pi^{*}$ transitions, while the absorption bands shown in the low-energy region in the visible region (between 430 and $560 \mathrm{~nm}$ ) were assigned to the $\pi-\pi^{*}$ and metal-to-ligand charge transfer (MLCT) transitions. When the spectra recorded for JM1 was compared with the spectra recorded for $\mathbf{H 3}$, it was observed that the spectra of JM1 exhibited a hypsochromic shift which was observed for both $\pi-\pi^{*}$ (blue-shifted by $20 \mathrm{~nm}$; from 292 to $272 \mathrm{~nm}$ ) and MLCT (blue-shifted by $11 \mathrm{~nm}$; from 550 to $539 \mathrm{~nm}$ ) transitions as the methoxy groups were introduced to the phenyl rings of the ancillary ligands of the complex. As shown in Figure 2(a) and Table 1, though absorption maxima of $\pi-\pi^{*}$ and MLCT for JM1 are blue shifted compared to H3, corresponding molar extinction coefficients are increased or reduced. A similar trend was observed for JM3 and JM5. When the methoxy group was introduced to the tail of the ancillary ligand of JM3, a hypsochromic shift was observed for both $\pi-\pi^{*}$ (276 to $270 \mathrm{~nm}$ ) and MLCT (550 to $536 \mathrm{~nm}$ ) transitions. A decrease by 6 and $14 \mathrm{~nm}$ was observed, respectively. The results indicated that the electron-donating methoxy substituent helped increase the energy gap (for $\pi-\pi^{*}$ and MLCT transitions). An analysis of the absorption spectra of the ruthenium(II)-complexes JM2, JM4, and JM6 revealed that the compounds exhibited extended $\pi$-conjugation (anchoring ligand: dcvphen). The extent of conjugation in these compounds was greater than the extent of conjugation exhibited by JM1, JM3, and JM5. The wavelengths were red-shifted by 21,23 , and $24 \mathrm{~nm}$ for the $\pi-\pi^{*}$ transitions $\left(\pi-\pi^{*}\right.$ transition in JM5: $\left.294 \mathrm{~nm}\right)$ and 10, 5, and $15 \mathrm{~nm}$ for the lower-energy MLCT transitions. However, the broad bands appeared in the range of 320-470 nm for JM2, JM4, and JM6. The broad nature of the bands could be attributed to the presence of the highly $\pi$-conjugated system and the ancillary and anchoring ligands. These features resulted in difficulties in determining the values of $\lambda_{\max }$.

3.3. PV Performance of the DSSCs Fabricated with Ruthenium(II) Complexes. The DSSCs were successfully fabricated using the synthesized heteroleptic ruthenium(II) complex sensitizers. The PV performances of the DSSCs fabricated using the prepared ruthenium(II) sensitizers were examined under conditions of 1 sun (AM $1.5 \mathrm{G}$, $100 \mathrm{~mW} \cdot \mathrm{cm}^{-2}$ ). The performance was compared to the performance of the reference (N719-sensitized DSSC) under the same conditions. Figures 3(a) and 3(b) show the typical photocurrent-voltage $(J-V)$ curves recorded for the DSSCs fabricated using JM1-JM6, H3, and N719. As shown in the figures, the DSSCs exhibited characteristic PV performances. Characteristic open-circuit voltages $\left(V_{O C} s\right)$, shortcircuit current densities $\left(J_{\mathrm{SC}} \mathrm{s}\right)$, fill factors $(F F \mathrm{~s})$, and PCEs were observed. The $V_{\mathrm{OC}}, J_{\mathrm{SC}}$, and $F F$ values of the reference DSSC fabricated with $\mathbf{N} 719$ were $0.69 \mathrm{~V}, 12.2 \mathrm{~mA} \cdot \mathrm{cm}^{-2}$, and 0.67 , respectively. The result corresponded to a PCE value of approximately $5.63 \%$. The recorded value agreed well with 


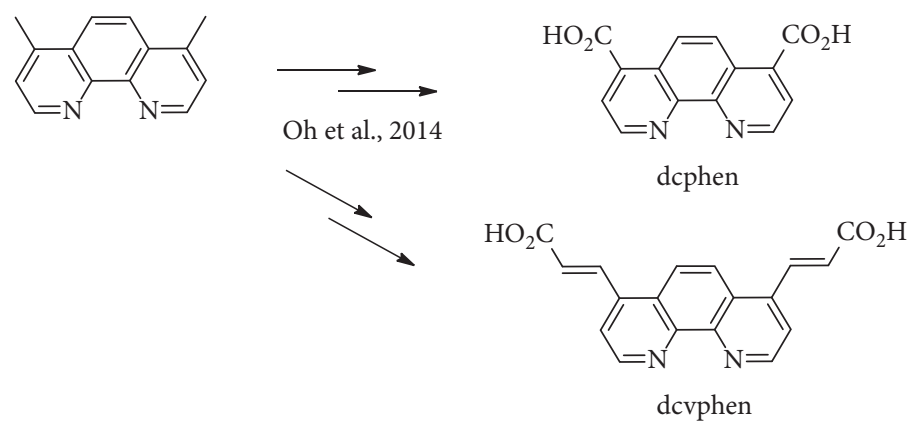

(a)
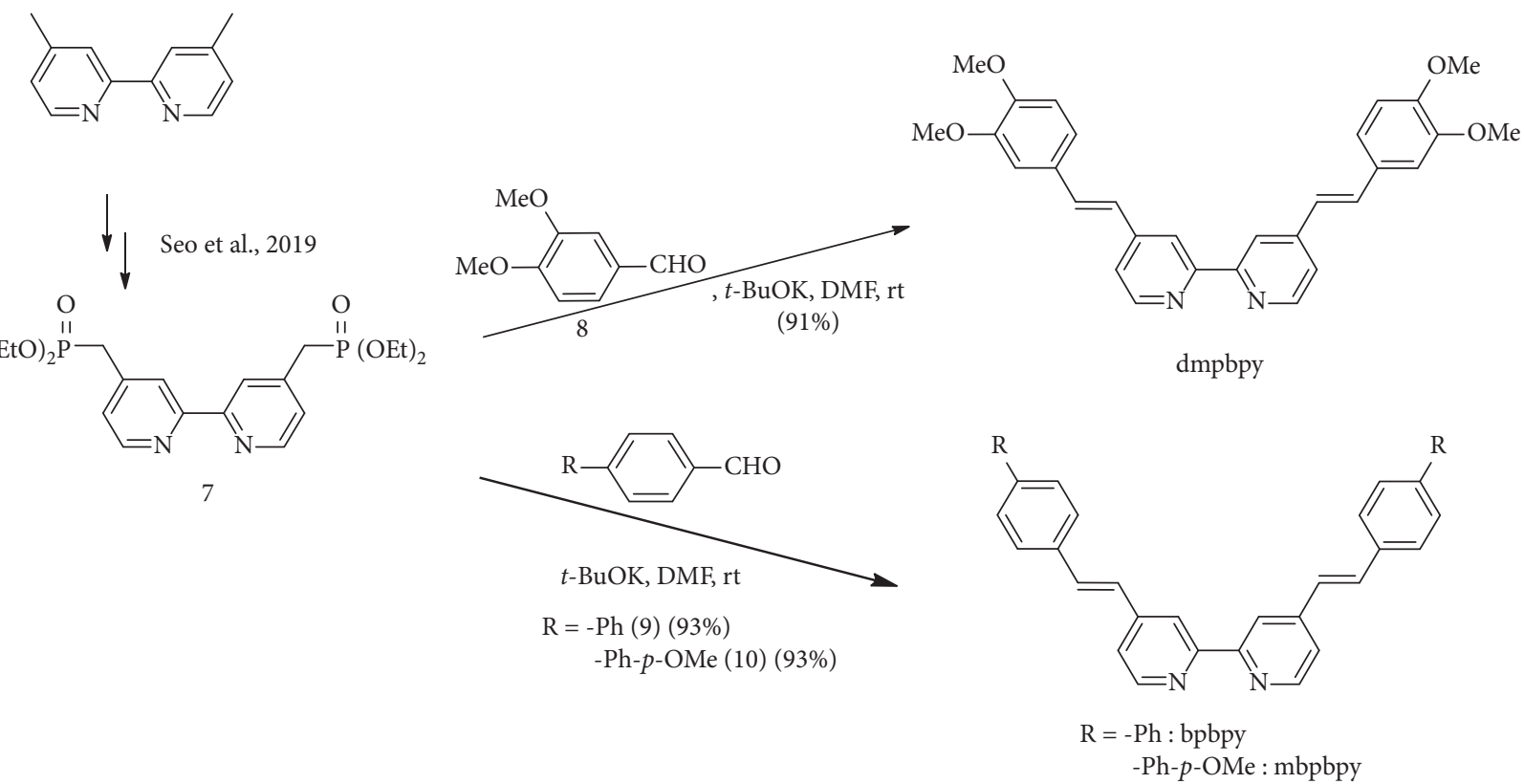

(b)

Scheme 1: Synthetic route for the preparation of the ligands under study.

the values previously reported by us [18]. The $V_{\mathrm{OC}}, J_{\mathrm{SC}}$, and $F F$ values of an $\mathbf{H 3}$-sensitized DSSC were $0.64 \mathrm{~V}$, $6.65 \mathrm{~mA} \cdot \mathrm{cm}^{-2}$, and 0.69 , respectively. The values corresponded to a PCE value of $2.98 \%$. The PV performance of this system was better than the performances of the $\mathbf{H}$-seriessensitized cells studied previously (PCE in the range of $0.64-2.98 \%)$ [18].

When the dimethoxy group was introduced in the scaffold of the bsbpy (ancillary) ligand in H3, i.e., dmpbpy (JM1), the JM1-sensitized DSSC exhibited the best device performance. The performance was better than the performance of the compounds in the JM-series reported herein. The $V_{\mathrm{OC}}, J_{\mathrm{SC}}$, and $F F$ values for the system were $0.63 \mathrm{~V}, 8.06 \mathrm{~mA} \cdot \mathrm{cm}^{-2}$, and 0.67 , respectively. The PCE value was $3.40 \%$. The PV performance of the JM1-sensitized DSSC was significantly better than the performances of the previously studied $\mathbf{H}$-series-sensitized DSSCs (PCE in the range of $0.64-2.98 \%$ ) (Lee et al.). The PCE value (3.40\%) recorded for the JM1-sensitized DSSC was approximately $71 \%$ of the PCE value recorded for the reference N719-sensitized DSSC (5.63\%). The lower PCE value of the JM1 system can be attributed to the extended $\pi$-conjugation. Extended $\pi$-conjugation can potentially result in a decrease in electron-collection efficiency. It can also promote the process of harvesting light. The second and third best performances (among the JM-series-sensitized DSSCs under study) were recorded for the JM5- and JM3-sensitized solar cells, respectively. The $J_{\mathrm{SC}}$ value was $6.41 \mathrm{~mA} \cdot \mathrm{cm}^{-2}$ for the JM5 system (and $3.55 \mathrm{~mW} \cdot \mathrm{cm}^{-2}$ for the JM3 system). The $V_{\mathrm{OC}}$ value was $0.60 \mathrm{~V}$ for the JM5 system (and $0.60 \mathrm{~V}$ for the JM3 system). The FF value was 0.66 for the JM5 system (and 0.68 for the JM3 system). The PCE value was 2.52\% for the JM5 system (and 1.45\% for the JM3 system). The JM2-, JM4-, and JM6-sensitized DSSCs exhibited poor PV performances (the PCE values were lower than $0.1 \%$ ). The PV performances of the DSSCs under study are summarized in Table 2.

The data presented in Table 2 revealed that an appropriate combination of the ancillary and anchoring ligands helps in optimizing the PV performances of the DSSCs fabricated using the heteroleptic ruthenium(II) complexes. Appropriate structural modifications for the ancillary and anchoring ligands also help in optimizing the PV performance of the DSSCs. First, the ancillary ligand of bsbpy (H3) was modified by introducing the dimethoxy (dmpbpy, JM1) 

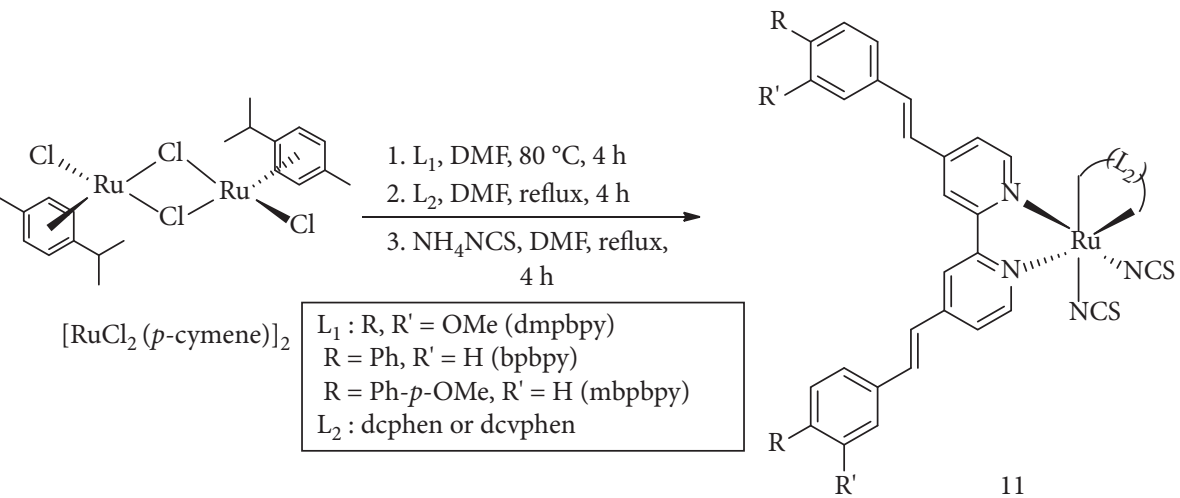

\begin{tabular}{c|c|c}
$\mathrm{L}_{1}$ & $\mathrm{~L}_{2}$ & complex \\
\hline dmpbpy & dcphen & $11 \mathrm{a}$ \\
dmpbpy & dcvphen & $11 \mathrm{~b}$ \\
bpbpy & dcphen & $11 \mathrm{c}$ \\
bpbpy & dcvphen & $11 \mathrm{~d}$ \\
mbpbpy & dcphen & $11 \mathrm{e}$ \\
mbpbpy & dcvphen & $11 \mathrm{f}$
\end{tabular}

mbpby devphen $\quad 11 \mathrm{f}$

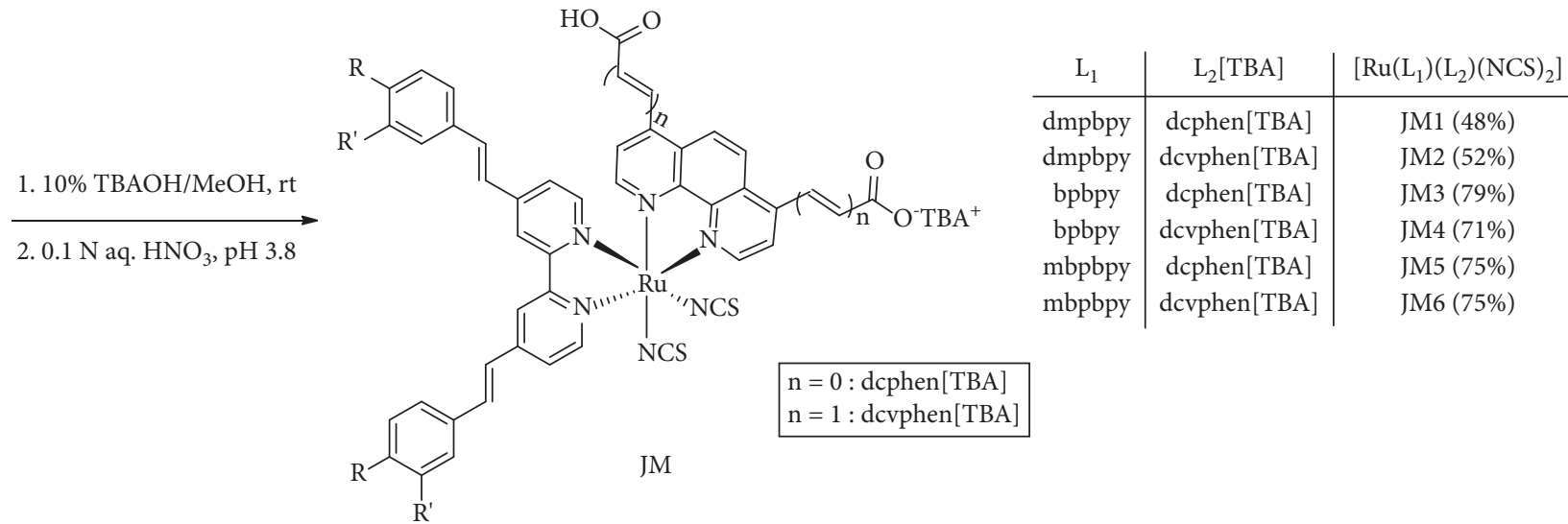

Scheme 2: Synthesis of heteroleptic ruthenium(II) complexes.

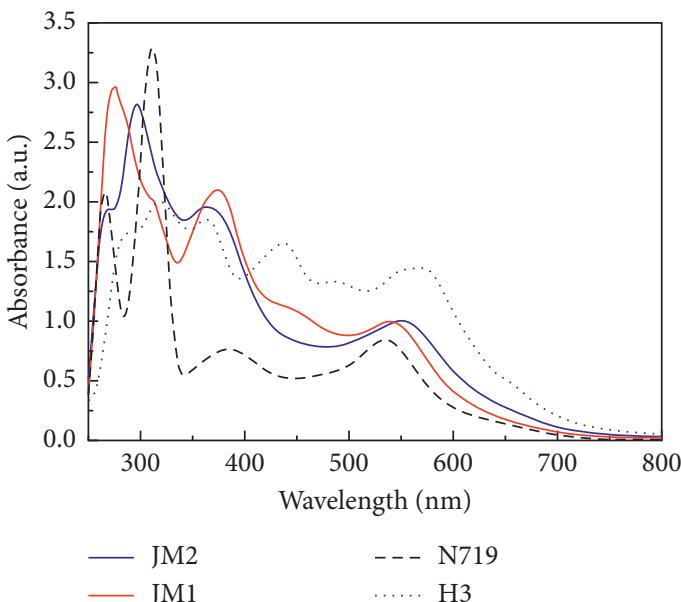

(a)

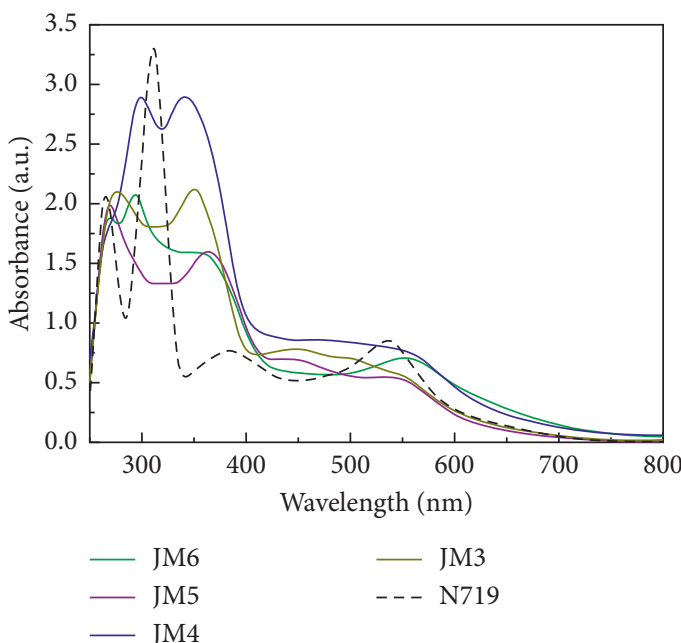

(b)

FIgURE 2: UV-vis absorption spectra of (a) JM1-JM2 including N719 and H3 and (b) JM3-JM6 including N719 measured at 298 K under ambient conditions (solvent: DMSO).

group. The lone pair of electrons present in oxygen in the system helped in achieving extended conjugation. The PCE value of the JM1-sensitized DSSC increased significantly from $2.98 \%$ to $3.40 \%$, although the $\pi-\pi^{*}$ and MLCT bands were blue-shifted. When the $\pi$-conjugation in the ancillary ligand of bsbpy (H3) was extended by introducing the extended phenyl (bpbpy, JM3) group, the PCE value of DSSC reduced significantly (from $2.98 \%$ to $1.45 \%$ ). Significant and interesting changes in the PV performances were observed when the electron-donating methoxy groups were 
TABLE 1: Absorption maxima $\left(\lambda_{\max }\right)$ and molar absorption coefficients $(\varepsilon)$ of JM1-JM6 and N719 (standard solution in DMSO; $1 \times 10^{-4}$ M).

\begin{tabular}{lccr}
\hline Complex & & Absorption maxima $\left(\lambda_{\max }(\mathrm{nm})\right)\left(\varepsilon\left(10^{4} \mathrm{M}^{-1} \mathrm{~cm}^{-1}\right)\right)$ & $\pi_{-}^{*}$ or MLCT \\
\hline H3 $^{\text {a }}$ & $\pi-\pi^{*}$ & $320(1.83) 437(1.54)$ & $550(1.33)$ \\
JM1 & $292(1.63)$ & $370(2.09) 449(1.09)$ & $539(0.99)$ \\
JM2 & $272(2.91)$ & $361(1.95)$ & $549(1.00)$ \\
JM3 & $293(2.78)$ & $350(2.11) 448(0.78)$ & $550(0.55)$ \\
JM4 & $276(2.09)$ & $341(2.88) 466(0.86)$ & $555(0.76)$ \\
JM5 & $299(2.88)$ & $363(1.59) 439(0.70)$ & $536(0.55)$ \\
JM6 & $270(1.98)$ & $353(1.59)$ & $551(0.71)$ \\
N719 & $269(1.86) 294(2.07)$ & $383(0.76)$ & $533(0.84)$ \\
\hline
\end{tabular}

${ }^{\mathrm{a}} \operatorname{Ref}[18]$.

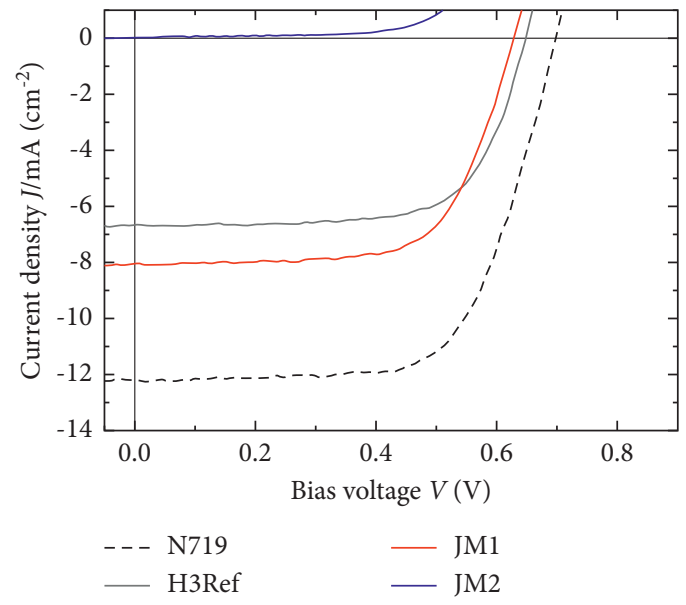

(a)

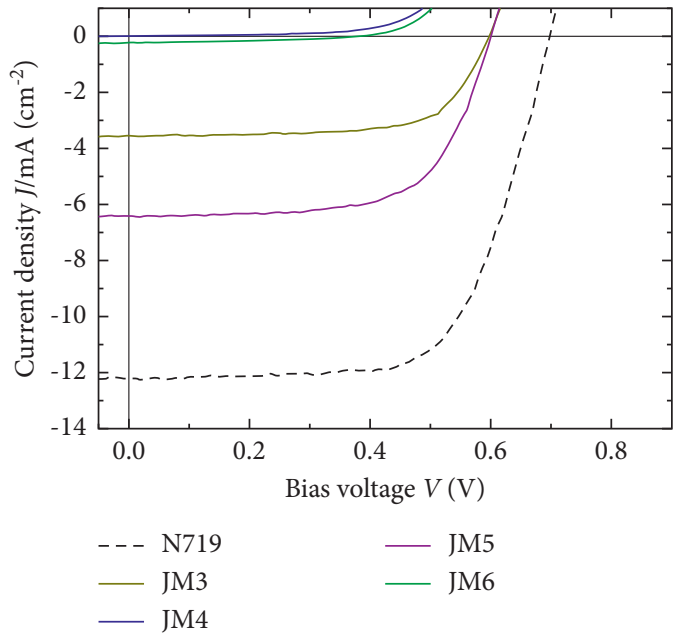

(b)

Figure 3: Photocurrent density-voltage $(J-V)$ characteristic curves of JM1-JM6 and N719-sensitized TiO ${ }_{2}$ nanocrystalline solar cells under conditions of 1 sun (AM 1.5G). Electrolyte mediator: $\mathrm{I}_{2}(0.05 \mathrm{M})$, LiI $(0.5 \mathrm{M})$, and tert-butylpyridine in acetonitrile $(0.5 \mathrm{M})$.

TABle 2: Photovoltaic parameters of the DSSCs sensitized using H3, JM1-JM6, and N719 dyes under the 1 sun (AM 1.5G, $100 \mathrm{~mW} \cdot \mathrm{cm}^{-2}$ ) illumination condition.

\begin{tabular}{lcccc}
\hline Dyes & $V_{\mathrm{OC}} / V$ & $J_{\mathrm{SC}} / \mathrm{mA} \cdot \mathrm{cm}^{-2}$ & $\mathrm{FF} /(\%)$ & $\mathrm{PCE} /(\%)$ \\
\hline H3 $^{\mathrm{a}}$ & 0.64 & 6.65 & 0.69 & 2.98 \\
JM1 & 0.63 & 8.06 & 0.67 & 3.40 \\
JM2 & 0.00 & 0.00 & - & 0.00 \\
JM3 & 0.60 & 3.55 & 0.68 & 1.45 \\
JM4 & 0.00 & 0.00 & - & 0.00 \\
JM5 & 0.60 & 6.41 & 0.66 & 2.52 \\
JM6 & 0.38 & 0.24 & 0.39 & 0.04 \\
N719 & 0.69 & 12.2 & 0.67 & 5.63 \\
\hline
\end{tabular}

${ }^{\mathrm{a}} \operatorname{Ref}[18]$.

introduced into the scaffolds of the ancillary ligands. The results were further validated when the JM5-sensitized DSSC was studied. The $\pi$-conjugation in the ancillary ligand of the phenyl-extended bsbpy in the JM5-sensitized DSSC was extended by introducing the electron-donating methoxy (mbpbpy, JM5) group. This resulted in the improvement of the PCE values (from $1.45 \%$ to $2.52 \%$ ). Improved PCE values were recorded for JM1 and JM5 when the electron-donating methoxy groups were substituted at the appropriate positions of the ancillary groups.
The anchoring ligands were structurally modified by replacing the dcphen (anchoring) ligands of the JM1, JM3, and JM5 with dcvphen (JM2, JM4, and JM6, respectively). The PV performances of the JM2-, JM4-, and JM6-sensitized DSSCs significantly decreased, and the PCE values recorded were less than $0.1 \%$. Extended $\pi$-conjugation in the anchoring ligand should improve the light-harvesting ability of the sensitizers. It was observed that the JM2, JM4, and JM6 sensitizers were significantly less efficient (in conserving power) than the JM1, JM3, and JM5 sensitizers. However, we could not explain the lower efficiencies of the JM2, JM4, and JM6 sensitizers. The low PCE values of the JM2-, JM4-, and JM6-sensitized DSSCs could be potentially attributed to the fact that the solubilities of these systems in the given solvent (isopropyl alcohol) were lower than the solubilities of the JM1, JM3, and JM5 sensitizers. This resulted in significantly reduced adsorption on the $\mathrm{TiO}_{2}$ surfaces.

\section{Conclusions}

Six new heteroleptic ruthenium(II) complexes (JM1-JM6), each containing a highly $\pi$-conjugated bipyridine ancillary ligand including methoxy-substituted analog $\left(\mathrm{L}_{1}\right)$ and a phenanthroline-type anchoring ligand $\left(\mathrm{L}_{2}\right)$ (dcphen or 
dcvphen; $\quad\left[\mathrm{Ru}(\mathrm{L})_{2}(\mathrm{NCS})_{2}\right][\mathrm{TBA}]_{2}$, where $\mathrm{L}_{1}=\mathrm{dmpbpy}$, bpbpy, or mbpbpy and $\mathrm{L}_{2}=\mathrm{dcphen}$ or dcvphen) were synthesized and characterized, and their physical and photovoltaic properties were investigated. Among the DSSCs fabricated with the heteroleptic ruthenium(II) complexes, the ruthenium(II) complex ligated with dmpbpy as the ancillary ligand and dcphen as the anchoring ligand (JM1) exhibited the maximum PCE (3.40\%). The PCE value recorded for the commercially available N719-sensitized solar cell (used as a reference) was $5.63 \%$. The ruthenium(II) complex ligated to mbpbpy as the ancillary ligand and dcphen as the anchoring ligand (JM5) exhibited the secondbest efficiency (PCE value: $2.52 \%$ ), and the ruthenium(II) complex ligated to bpbpy as the ancillary ligand and dcphen as the anchoring ligand (JM3) exhibited a PCE value of $1.45 \%$. Interestingly, when the appropriate sites of the ancillary groups in $\mathbf{H 3}$ (or JM3) were substituted with the electron-donating methoxy groups, the PCE values of the DSSCs fabricated using JM1 or JM5 increased significantly. In contrast, the sensitized DSSCs fabricated using the ruthenium(II) complex ligated to dcvphen as the anchoring ligand (JM2, JM4, and JM6) exhibited poor PV performance. The PCE values of these systems were lower than $0.1 \%$.

\section{Data Availability}

All data used to support this study are included in the article.

\section{Conflicts of Interest}

The authors declare no conflicts of interest.

\section{Acknowledgments}

The authors would like to thank the Basic Science Research Program through the National Foundation of Korea (NRF) for funding this work. Grant numbers of the Korean Government (MEST) are 2019R1G1A1008265 (H. Lee) and 2020R1A2B5B03097060 (B. Park).

\section{References}

[1] A. Hagfeldt, G. Boschloo, L. Sun, L. Kloo, and H. Pettersson, "Dye-sensitized solar cells," Chemical Reviews, vol. 110, no. 11, pp. 6595-6663, 2010.

[2] S. Aghazada and M. K. Nazeeruddin, "Ruthenium complexes as sensitizers in dye-sensitized solar cells," Inorganics, vol. 6, no. 2, pp. 52-105, 2018.

[3] B. O'Regan and M. Grätzel, “A low-cost, high-efficiency solar cell based on dye-sensitized colloidal $\mathrm{TiO}_{2}$ films," Nature, vol. 353, no. 6346, pp. 737-740, 1991.

[4] M. K. Nazeeruddin, A. Kay, I. Rodicio et al., "Conversion of light to electricity by cis- $\mathrm{X}_{2}$ bis $\left(2,2^{\prime}\right.$-bipyridyl- $4,4^{\prime}$-dicarboxylate) ruthenium(II) charge-transfer sensitizers $\left(X=\mathrm{Cl}^{-}, \mathrm{Br}^{-}\right.$, $\mathrm{I}^{-}, \mathrm{CN}^{-}$, and $\left.\mathrm{SCN}^{-}\right)$on nanocrystalline titanium dioxide electrodes," Journal of the American Chemical Society, vol. 115, no. 14, pp. 6382-6390, 1993.

[5] M. K. Nazeeruddin and K. Kalyanasundaram, "Acid-base behavior in the ground and excited states of ruthenium(II) complexes containing tetraimines or dicarboxybipyridines as protonatable ligands," Inorganic Chemistry, vol. 28, no. 23, pp. 4251-4259, 1989.

[6] M. K. Nazeeruddin, P. Péchy, T. Renouard et al., "Engineering of efficient panchromatic sensitizers for nanocrystalline $\mathrm{TiO}_{2}-$ based solar cells," Journal of the American Chemical Society, vol. 123, no. 8, pp. 1613-1624, 2001.

[7] B. Pashaei, H. Shahroosvand, M. Graetzel, and M. K. Nazeeruddin, "Influence of ancillary ligands in dyesensitized solar cells," Chemical Reviews, vol. 116, no. 16, pp. 9485-9564, 2016.

[8] G. C. Vougioukalakis, T. Stergiopoulos, G. Kantonis et al., "Terpyridine- and 2,6-dipyrazinylpyridine-coordinated ruthenium(II) complexes: synthesis, characterization and application in $\mathrm{TiO}_{2}$-based dye-sensitized solar cells," Journal of Photochemistry and Photobiology A: Chemistry, vol. 214, no. 1, pp. 22-32, 2010.

[9] Z.-S. Wang, C.-H. Huang, Y.-Y. Huang et al., "Photoelectric behavior of nanocrystalline $\mathrm{TiO}_{2}$ electrode with a novel terpyridyl ruthenium complex," Solar Energy Materials and Solar Cells, vol. 71, no. 2, pp. 261-271, 2002.

[10] T. Funaki, M. Yanagida, N. Onozawa-Komatsuzaki, Y. Kawanishi, K. Kasuga, and H. Sugihara, "Ruthenium(II) complexes with $\pi$ expanded ligand having phenylene-ethynylene moiety as sensitizers for dye-sensitized solar cells," Solar Energy Materials and Solar Cells, vol. 93, no. 6-7, pp. 729-732, 2009.

[11] S.-H. Yang, K.-L. Wu, Y. Chi, Y.-M. Cheng, and P.-T. Chou, "Tris(thiocyanate)ruthenium(II) sensitizers with functionalized dicarboxyterpyridine for dye-sensitized solar cells," Angewandte Chemie International Edition, vol. 123, no. 36, pp. 8420-8424, 2011.

[12] M. Kimura, J. Masuo, Y. Tohata et al., "Improvement of $\mathrm{TiO}_{2} /$ dye/electrolyte interface conditions by positional change of alkyl chains in modified panchromatic Ru complex dyes," Chemistry-A European Journal, vol. 19, no. 3, pp. 1028-1034, 2013.

[13] N. Onozawa-Komatsuzaki, M. Yanagida, T. Funaki, K. Kasuga, K. Sayama, and H. Sugihara, "Near-IR sensitization of nanocrystalline $\mathrm{TiO}_{2}$ with a new ruthenium complex having a 2,6-bis (4-carboxyquinolin-2-yl) pyridine ligand," Inorganic Chemistry Communications, vol. 12, no. 12, pp. 1212-1215, 2009.

[14] N. Tomar, A. Agrawal, V. S. Dhaka, and P. K. Surolia, "Ruthenium complexes based dye sensitized solar cells: fundamentals and research trends," Solar Energy, vol. 207, pp. 59-76, 2020.

[15] J. Tak, M. Kim, S. Park et al., "Synthesis and photophysical properties of new ruthenium(II)charge-transfer sensitizers containing a 4,7-bis(E-carboxyvinyl)-1,10-phenanthroline ligand," Monatshefte für Chemie-Chemical Monthly, vol. 145, no. 7, pp. 1101-1108, 2014

[16] H. Oh, J. Kim, S. H. Yun et al., "Synthesis of heteroleptic Ru (II)complexes ligated with 1,3-dihydro-1,1,3,3-tetramethyl7,8-diazacyclopenta[1]phenanthren-2-one and application in dye-sensitized solar cells," Synthetic Metals, vol. 198, pp. 260-266, 2014.

[17] Y. R. Choi, W. Lee, S. H. Yun et al., "Dinuclear Ru(II) complexes bridged with 5-(2-[2,2'-bipyridin]-5-ylethynyl)$2,2^{\prime}$-bipyridine ligand and ligated to ancillary $\alpha$-diimine ligand: synthesis and application to dye-sensitized solar cells," Monatshefte für Chemie-Chemical Monthly, vol. 148, no. 12, pp. 2051-2059, 2017.

[18] J. Lee, J. Seo, Y. R. Choi et al., "Synthesis and characterization of heteroleptic $\mathrm{Ru}(\mathrm{II})$ complexes based on 4,4'-bis((E 
)-styryl)-2,2'-bipyridine as ancillary ligand and application for dye-sensitized solar cells," Helvetica Chimica Acta, vol. 101, no. 5, Article ID e1800030, 2018.

[19] J. Seo, M. Jeong, S. Y. Na et al., "Synthesis and characterization of novel heteroleptic $\mathrm{Ru}(\mathrm{II})$ bipyridine complexes for dyesensitized solar cell applications," Monatshefte für ChemieChemical Monthly, vol. 150, no. 8, pp. 1445-1452, 2019. 